\title{
Terminal Stages in the Biosynthesis of Haemoglobin
}

\author{
THE RELEASE OF PROTEIN FROM RETICULOCYTE RIBOSOMES
}

\author{
By A. J. MORRIS* \\ Department of Biochemistry, National Institute for Medical Research, Mill Hill, London, N.W. 7
}

(Received 19 August 1963)

Studies of the mechanism of protein biosynthesis which have been conducted with cell-free systems consisting of ribosomes, soluble enzymes and cofactors readily distinguish three general stages in the synthetic process (see Simpson, 1962). These consist of:

Amino acid + ATP + activating enzyme $\rightleftharpoons$ amino acid-AMP-enzyme $+\mathrm{PP}_{1}$

Amino acid-AMP-enzyme $+\mathrm{s}-\mathrm{RNA} \rightleftharpoons$ amino acid-s-RNA + activating enzyme + AMP

Amino acid-s-RNA + ribosomes

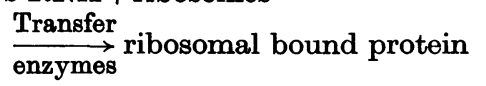

A portion of the radioactive amino acids incorporated into peptide linkages by cell-free systems was found not to sediment with the ribosomal particles (Simkin, 1958). This observation led to the proposal that the synthetic process contains yet another reaction:

Ribosomal bound protein $\rightarrow$ soluble protein

$$
+ \text { ribosomes }
$$

The labelled protein found in the soluble fraction after incubation of reticulocyte ribosomes in a complete cell-free system has been shown to consist of haemoglobin together with much uncharacterized protein (Schweet, Lamfrom \& Allen, 1958; Rabinovitz \& Fischer, 1962). Chromatographic analysis of the labelled soluble protein formed on incubation of ${ }^{14} \mathrm{C}$-labelled ribosomes with unlabelled components in the complete cell-free system gave comparable results (Morris \& Schweet, 1961). Rapid labelling of a soluble non-haem protein by intact reticulocytes has been reported by Rabinovitz \& Olson (1959). Ribosomal particles have been implicated also in the incorporation of labelled iron into haemoglobin (Rabinovitz \& Oslon, 1958), but it is not clear how the four haemoglobin sub-units are assembled from their constituent parts (see Margoliash, 1961). There is considerable evidence, however, to indicate that most of the protein synthesized by reticulocytes and cell-free preparations from reticulocytes is

* Present address: Department of Biochemistry, Michigan State University, East Lansing, Mich., U.S.A. directed towards an eventual formation of haemoglobin (Kruh \& Borsook, 1956; Dintzis, Borsook \& Vinograd, 1958; Schweet et al. 1958; Wallace, Squires \& Ts'o, 1961; Lingrel \& Borsook, 1963).

Although a number of publications dealing with the release of protein from ribosomal particles and 'releasing factors' have appeared, a critical study of the independent existence of such a 'release' stage of protein synthesis has not been conducted. It would seem that, until the contributions of reactions (1)-(3) to reaction (4) have been evaluated, the possibility remains that the reported 'releasing factors' may be the enzymic components of reactions (1)-(3).

The present paper reports the study of the influence of the polypeptide-forming stages of protein biosynthesis on the appearance of soluble protein in a cell-free system from rabbit reticulocytes. Though the amount of protein that appeared in the soluble phase was greatly enhanced by components already known to be involved in the incorporation of amino acids into polypeptides, it has been possible to demonstrate that the release of protein from the ribosomal particle is a separate reaction, independent of polypeptide formation.

Some of the results presented below have been reported briefly elsewhere (Morris, 1963).

\section{MATERIALS}

Nucleoside triphosphates were obtained from the Sigma Chemical Co., St Louis, Mo., U.S.A. Phosphoenolpyruvic acid (silver-barium salt), pyruvate kinase, tris and GSH were from C.F. Boehringer und Soehne G.m.b.H., Mannheim, Germany. Radioactive amino acids were obtained from The Radiochemical Centre, Amersham, Bucks. Crystalline bovine ribonuclease and crystallized bovine serum albumin were purchased from the Armour Pharmaceutical Company Ltd., Eastbourne, Sussex. Heparin (Pularin) was B.P. grade (Evans Medical Ltd., Liverpool). Spermine was recrystallized as the hydrochloride after treatment with Norite $A$ and neutralized before use. Nembutal (B.P.) was from Abbott Laboratories Ltd., Queenborough, Kent. CM-cellulose (0.60 m-equiv./g.) was obtained from Serva, Heidelberg, Germany; Amberlite CG-50 resin was obtained from British Drug Houses Ltd., Poole, Dorset. Other materials used were of analytical grade. 


\section{METHODS}

Analytical procedures. The protein concentrations of the ribosomal suspensions and the purified supernatant enzyme fraction were determined by the method of Lowry, Rosebrough, Farr \& Randall (1951) as modified by Oyama \& Eagle (1956), with crystalline bovine serum albumin as standard protein.

Samples containing radioactive protein were prepared for analysis by precipitation with $5 \%(w / v)$ trichloroacetio acid; the precipitate was collected by centrifugation and washed by resuspension and resedimentation in $5 \%$ trichloroacetic acid. The resultant pellet was completely dissolved in $0.5 \mathrm{ml}$. of $\mathrm{N}-\mathrm{NaOH}$ and reprecipitated with $5 \%$ trichloroacetic acid. The pellet was suspended in $3 \mathrm{ml}$. of $5 \%$ trichloroacetic acid and heated at $90^{\circ}$ for $15 \mathrm{~min}$., cooled and additional $5 \%$ trichloroacetic acid added. The protein precipitate was washed once more with $5 \%$ trichloroacetic acid, then with $6 \mathrm{ml}$. of acetone, then with $2 \mathrm{ml}$. of acetone plus $4 \mathrm{ml}$. of diethyl ether and finally with ether alone. The final protein precipitate was dried in air and dissolved in $98 \%$ formic acid at a concentration of approx. $6.6 \mathrm{mg} . / \mathrm{ml}$. A $0.3 \mathrm{ml}$. portion of this solution was plated on tared silicone-coated aluminium planchets (area $\left.1.7 \mathrm{~cm} .{ }^{2}\right)$ and dried overnight in vacuo over $\mathrm{P}_{2} \mathrm{O}_{5}$ and $\mathrm{KOH}$. The dried planchets were weighed and counted $(2000$ 3000 counts) in an automatic Geiger counter with a thin mica window (efficiency approx. 10\%). Where indicated, counting was performed with a low-background NuclearChicago automatic Geiger counter (efficiency approx. $28 \%$ ). All values have been corrected for self-absorption and background and have been calculated as total counts/min./ assay system at infinite thinness.

When necessary, sufficient bovine serum albumin was added to the assay system before the precipitation with trichloroacetic acid to bring the total protein content to 4-6 mg.

Preparation of reagents. Phosphoenolpyruvate was prepared from the silver-barium salt with the aid of $\mathrm{KCl}$ and $\mathrm{K}_{2} \mathrm{SO}_{4}$ and neutralized with $\mathrm{KOH}$. When the effects of $\mathrm{K}^{+}$ ion concentrations were to be studied the phosphoenolpyruvate was prepared with the corresponding acids and titrated with tris base. GSH was adjusted to $\mathrm{pH} 6$ and the nucleoside triphosphate solutions were adjusted to $\mathrm{pH} 7$ in similar ways before use.

Biological materials. Male Sandy Lop rabbits weighing 5-6 lb. were made reticulocytic by four daily subcutaneous injections of $1 \mathrm{ml}$. of $\mathbf{2 . 5} \%$ neutralized phenylhydrazine. After 2 more days without injection over $80 \%$ of the circulating cells were reticulocytes when determined according to the method of Neuberger \& Niven (1951). On the sixth day after the beginning of the injections the animals received a solution containing 2000 i.u. of heparin and $60 \mathrm{mg}$. of Nembutal by intravenous injection. Blood was collected immediately by heart puncture and washed, lysed and fractionated by the method of Allen \& Schweet (1962), except that the layer of white cells was removed by aspiration after the washing and centrifugation of the cells. After sedimentation of the reticulocyte ribosomes by centrifugation at $78000 \mathrm{~g}$ for $90 \mathrm{~min}$., the ribosomal pellets were resuspended in a small volume of cold $0.25 \mathrm{M}$-sucrose and added to the preincubation mixtures described below.

The purified supernatant enzyme fraction was prepared by the addition of powdered ammonium sulphate to the
$78000 \mathrm{~g}$ supernatant to yield the protein fraction that was precipitated between 40 and $70 \%$ saturation at $0^{\circ}$. This

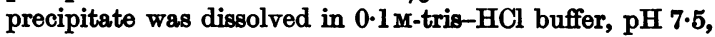
containing GSH (1 mM) and reprecipitated by the addition of ammonium sulphate to $70 \%$ saturation. The final protein precipitate, which was relatively free of haemoglobin, was dissolved in a small volume of a solution containing $0.02 \mathrm{M}$ tris-HCl buffer, $\mathrm{pH} \mathrm{7 \cdot 5}$, containing EDTA (1 mM), $\mathrm{MgCl}_{2}$ (1 $\mathrm{mM}$ ) and GSH (1 $\mathrm{mM}$ ), and dialysed overnight against 100 vol. of the same solution. The dialysed enzyme preparation was stored at $-18^{\circ}$ in the presence of $0.02 \mathrm{M}-\mathrm{GSH}$ and was stable for 2-3 weeks. For those experiments concerned with the effects of transfer RNA in the cell-free systems, the $78000 \mathrm{~g}$ supernatent solution was treated with protamine sulphate, to precipitate the RNA, before the ammonium sulphate fractionation procedure. The precipitate from the protamine sulphate treatment was collected and used to prepare reticulocyte transfer RNA (Allen \& Schweet, 1962). When the RNA-precipitation step was omitted the purified supernatant enzyme fraction contained saturating amounts of transfer RNA. For those experiments requiring enzyme fractions containing a low concentration of GSH the stored enzyme solution was dialysed for several hours against 100-200 vol. of the above dialysis mixture immediately before use.

All biological materials were prepared at $0-4^{\circ}$. Highspeed centrifuging was carried out in a Spinco model $\mathrm{L}$ preparative ultracentrifuge.

Parallel preincubation procedures. (a) For the cell-free system. The preincubation medium contained ATP (1 mM), phosphoenolpyruvic acid $(2.5 \mathrm{~mm})$, pyruvate kinase (10 $\mu \mathrm{g} . / \mathrm{ml}$.), 19 amino acids $(0.05 \mathrm{~mm}$ each), from which Lvaline had been omitted (Matthaei \& Nirenberg, 1961), GSH (0.02 M), KCl (0.05 M), $\mathrm{MgCl}_{2}$ (4 mM), tris-HCl buffer, pH $7.5(0.05 \mathrm{M})$, ribonucleoprotein $(5 \mathrm{mg} . / \mathrm{ml}$.), purified supernatant enzyme fraction (with transfer RNA) (5 mg./ $\mathrm{ml}$. ) and $\left[{ }^{14} \mathrm{C}\right]$ valine (specific activity $6.5 \mu \mathrm{c} / \mu \mathrm{mole}$ ) $(0.05 \mathrm{~mm})$. In a separate container an identical mixture was prepared except that unlabelled L-valine was added in the place of the radioactive amino acid. Each solution was then incubated for $10 \mathrm{~min}$. at $37^{\circ}$ and the reaction was stopped by the addition of 10-12 vol. of a cold solution containing sucrose $(0.25 \mathrm{M}), \mathrm{KHCO}_{3}(17.5 \mathrm{mM})$ and $\mathrm{MgCl}_{2}$ (2 mM). A 100-fold excess of unlabelled L-valine acid was then added to the ${ }^{14} \mathrm{C}$-labelled system and the ribosomes were isolated by centrifugation as described above. The ribosomal pellets were resuspended in a small volume of $0.25 \mathrm{M}$-sucrose, centrifuged at $10000 \mathrm{~g}$ for $10 \mathrm{~min}$. and the supernatant solution was stored at $-18^{\circ}$.

The parallel cell-free preincubation procedure thus yielded ${ }^{14} \mathrm{C}$-labelled ribosomes and the corresponding unlabelled ribosomes that had been subjected to an identical procedure of preparation.

(b) For the whole-cell system. Intact washed reticulocytes were preincubated by a modification of the method of Borsook, Fischer \& Keighley (1957) in a solution that contained $0.30 \mathrm{ml}$. of packed cells $/ \mathrm{ml}$., ferrous ammonium sulphate (0.1 mM), tris-HCl buffer, pH 7.5 (0.01 mM), rabbit plasma (0.05 ml./ml.), $\mathrm{NaCl}(0.072 \mathrm{M}), \mathrm{KCl}(2.9 \mathrm{~mm}), \mathrm{MgCl}_{2}$ (4.1 mM), an amino acid mixture, from which leucine had been omitted (Borsook, Deasy, Haagen-Smit, Keighley \& Lowy, 1952) $\left(0 \cdot 15 \mathrm{ml} . / \mathrm{ml}\right.$.) and [ $\left.{ }^{14} \mathrm{C}\right]$ leucine (specific activity $6.0 \mu \mathrm{c} / \mu \mathrm{mole})(0.025 \mathrm{~mm})$. In a separate container an identical mixture was prepared, except that unlabelled leucine was 
substituted for the ${ }^{14} \mathrm{C}$-labelled amino acid. Each reaction mixture was incubated for $5 \mathrm{~min}$. at $37^{\circ}$ and the reaction was stopped by the addition of a cold solution containing $\mathrm{NaCl}(0 \cdot 13 \mathrm{M}), \mathrm{KCl}(5 \mathrm{mM})$ and $\mathrm{MgCl}_{2}(7.5 \mathrm{~mm})$. The cells were washed twice more and the ribosomes were isolated by the usual procedure. Washed ribosomes were then prepared by resuspension and sedimentation (Allen \& Schweet, 1962). The washed ribosome pellets were resuspended in $0.25 \mathrm{M}$-sucrose, centrifuged at $10000 \mathrm{~g}$ for $10 \mathrm{~min}$. and the supernatant solution was stored at $-18^{\circ}$.

Simultaneous assay of the release of protein from ribosomal particles and the incorporation of amino acids into peptide linkage. Ribosomes labelled with ${ }^{14} \mathrm{C}$-labelled amino acids, from the preincubation procedures described above, were incubated in cell-free systems containing the corresponding unlabelled amino acid and other components as indicated. After incubation at $37^{\circ}$, the reaction mixtures were chilled and transferred to $4 \mathrm{ml}$. cellulose centrifuge tubes with the aid of cold $0.25 \mathrm{M}$-sucrose (final vol. $3.5 \mathrm{ml}$.). Ribosomes were reisolated by centrifugation at $105000 \mathrm{~g}$ for $60 \mathrm{~min}$. The supernatant fractions were removed by decantation and the ${ }^{14} \mathrm{C}$-labelled-protein contents of the supernatant fractions determined. The amount of ${ }^{14} \mathrm{C}$-labelled protein released from the ribosomal particle was calculated by subtracting the amount of ${ }^{14} \mathrm{C}$-labelled protein present in the supernatant fraction either of a complete assay system (see Table 2) kept at $0^{\circ}$ or of an incubated sample from which the nucleoside triphosphates and ATP-generating system had been omitted. Both procedures yielded essentially the same basal value (approx. $10 \%$ of total radioactivity).

Amino acid incorporation into protein was determined by incubating unlabelled ribosomes, obtained from the parallel preincubation procedures described above, in cellfree systems containing the corresponding ${ }^{14} \mathrm{C}$-labelled amino acid and other components, as indicated. After incubation at $37^{\circ}$, the reaction mixtures were chilled and trichloroacetic acid was added to precipitate total protein. The precipitates were then washed and plated and the total ${ }^{14} \mathrm{C}$-labelled protein was determined as described above.

Chromatography of haemoglobin. The ${ }^{14} \mathrm{C}$-labelled protein in the supernatant fraction obtained from a large-scale (15-fold) incubation of cell-free labelled ribosomes in the isolated release system (see the Results section) was pressure-dialysed for 2 days at $4^{\circ}$ against 1 l. of 'no. 2 buffer' of Allen, Schroeder \& Balog (1958). Carrier rabbit haemoglobin was prepared from the $78000 \mathrm{~g}$ supernatant of the cell lysate by ammonium sulphate fractionation between 70 and $90 \%$ saturation at $0^{\circ}$. After dialysis of the haemoglobin preparation against $1 \mathrm{mm-tris-HCl}$ buffer, pH 7.5, a $40 \mathrm{mg}$. portion was combined with the labelled supernatant material from above (final vol. $2 \cdot 60 \mathrm{ml}$.) and added to a column $(25 \mathrm{~cm} . \times 1 \mathrm{~cm}$.) of Amberlite CG-50. Chromatography was conducted by a modification of the method of Allen et al. (1958). After elution with $98 \mathrm{ml}$. of no. 2 buffer, the eluent was changed to no. 2 buffer of double the usual concentration and chromatography was continued until the carrier haemoglobin had been eluted from the column. The extinction of each $2 \mathrm{ml}$. fraction was determined at 260, 280 and $415 \mathrm{~m} \mu$ by using the Unicam SP. 500 spectrophotometer with $1 \mathrm{~cm}$. cuvettes. Haemoglobin was estimated by the method of Warburg \& Christian (1942). Bovine serum albumin was added to fractions from the non-haemoglobin regions of the column eluate to facilitate analysis for ${ }^{14} \mathrm{C}$-labelled protein.
Adjacent fractions throughout the haemoglobin peak were pooled to provide sufficient protein for convenient handling (3-6 mg.). The samples were then washed and analysed for total ${ }^{14} \mathrm{C}$-labelled protein as described above.

Chromatography of globin. The supernatant fraction obtained from a large-scale incubation of cell-free labelled ribosomes in the isolated protein-release system was incubated for $10 \mathrm{~min}$. at $37^{\circ}$ in the presence of $45 \mu \mathrm{g}$. of bovine ribonuclease $/ \mathrm{ml}$. The reaction mixture was chilled, combined with carrier haemoglobin (see the preceding section) and added dropwise to $30 \mathrm{vol}$. of cold $\left(-15^{\circ}\right)$ acetone containing $\mathrm{HCl}(0.06 \mathrm{~N})$. After $30 \mathrm{~min}$. of gentle stirring the protein precipitate was collected by low-speed centrifugation at $-10^{\circ}$, dissolved in $5 \mathrm{ml}$. of water and dialysed overnight (at $5^{\circ}$ ) against 11 . of pyridine-formate buffer [0.02 M-pyridine (redistilled) and $0.2 \mathrm{~N}$-formic acid]. The dialysed sample was added to a CM-cellulose column $(7 \mathrm{~cm} . \times 2.5 \mathrm{~cm}$.) that had been equilibrated with the same buffer. A linear gradient of from 0.02M-pyridine-0.2Nformic acid to $0 \cdot 2 \mathrm{M}$-pyridine-2N-formic acid in $200 \mathrm{ml}$. was applied at room temperature $\left(20^{\circ}\right)$ and the $\alpha$ - and $\beta$-chains of rabbit globin were eluted as described by Dintzis (1961). The extinction of each $3 \mathrm{ml}$. fraction was determined at $280 \mathrm{~m} \mu$. The fractions were pooled as indicated and analysed for total ${ }^{14} \mathrm{C}$-labelled protein. Bovine serum albumin was added to fractions from the non-globin portions of the column eluate to facilitate analysis of ${ }^{14} \mathrm{C}$ labelled protein. Globin concentrations were estimated from the extinction at $280 \mathrm{~m} \mu(E \mathbf{0 . 8 3 0}$ for a concentration of $1 \mathrm{mg} . / \mathrm{ml}$. as determined colorimetrically). Radioactivity was determined with the low-background counter.

\section{RESULTS}

\section{Ribosomal structure and the release of protein}

The biosynthesis of haemoglobin by reticulocyte ribosomes has been shown to proceed by way of ribosomal-bound intermediates possessing the properties of polypeptides (Dintzis et al. 1958; Rabinovitz \& Olson, 1959; Morris \& Schweet, 1961). In order to study the emergence of these precursors as soluble protein, it was necessary first to examine the stability of ribosomal particles during the incubation of cell-free ribosomes. The presence of metal-chelating agents (Chao, 1957), high concentrations of nucleoside triphosphates (Sachs, 1957) and extremes of $\mathbf{M g}^{2+}$ ion concentration (Hamilton \& Petermann, 1959), which are known to degrade ribosomal particles, all produce non-sedimentable ${ }^{14} \mathrm{C}$-labelled protein by degradation of labelled reticulocyte ribosomes. Characterization of this non-specific release has been reported by Morris \& Schweet (1961).

Though the incubation conditions employed in the present work resulted in redistribution of the rapidly sedimenting particles into $78 \mathrm{~s}$ particles (Warner, Rich \& Hall, 1962), particle sub-units that sedimented more slowly than $78 \mathrm{~s}$ were present in only trace amounts and did not increase noticeably during $40 \mathrm{~min}$. at $37^{\circ}$ (Fig. 1). Disinte- 
gration of labelled ribosomes during incubation does not therefore contribute appreciably to the appearance of ${ }^{14} \mathrm{C}$-labelled protein in the soluble fraction (see Hultin, Leon \& Cerasi, 1961).

\section{Effects of ribonuclease on the incorporation of amino acids and the release of proteins}

Though ribosomal particles are relatively resistant to the degradative action of bovine ribonuclease (Tissieres \& Watson, 1958), the ability of cell-free systems to incorporate amino acids into protein is extremely sensitive to low concentrations of ribonuclease (Arnstein, 1961). An analysis of the effects of this enzyme on the incorporation of amino acids and the release of proteins (Fig. 2) revealed marked differences. In systems devoid of added transfer RNA, those concentrations of ribonuclease that depressed the incorporation of amino acids by $80 \%$ had little or no effect on the energy-dependent release of proteins. Thus the

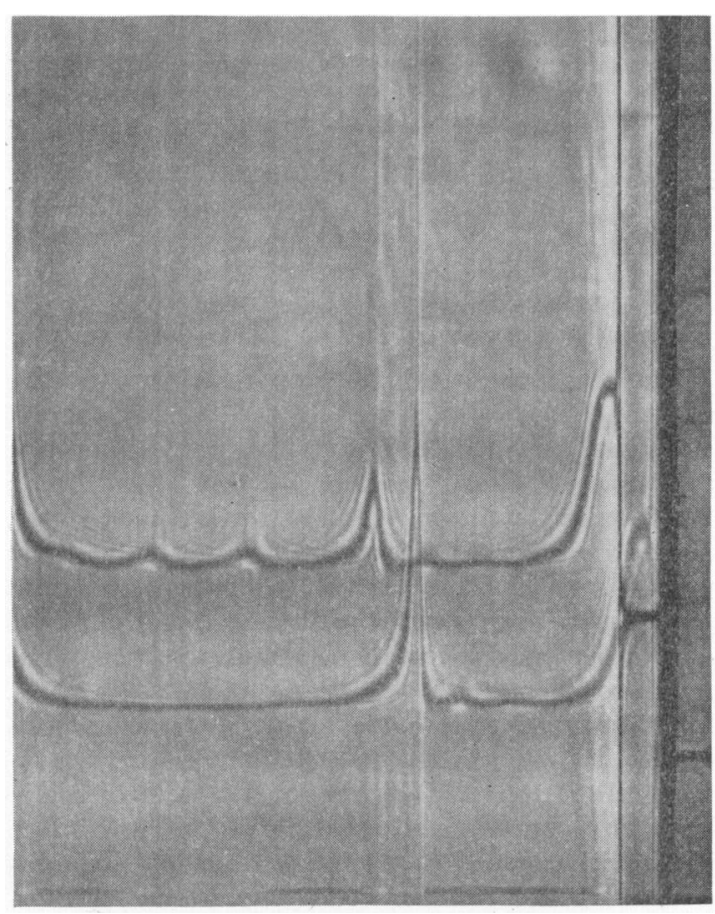

Fig. 1. Stability of ribosomal particles during incubation. Cell-free ribosomes (5 mg.) were incubated in the complete system (soe Table 2) for $40 \mathrm{~min}$. at $37^{\circ}$. The reaction mixture was chilled and transferred to a $1.2 \mathrm{~cm}$. cell. A duplicate assay that had remained at $0^{\circ}$ was placed in a $1.2 \mathrm{~cm}$. prismatic cell (top). The photograph was taken approx. $15 \mathrm{~min}$. after attaining $42040 \mathrm{rev} . / \mathrm{min}$. in the Spinco model E analytical ultracentrifuge (at $8^{\circ}$ ). Sedimentation was from right to left. incorporation of amino acids and the release of proteins are not rigidly linked processes but, rather, two processes that can proceed simultaneously at different rates.

\section{Effects of factors required for the incorporation of amino acids on the release of proteins}

Table 1 reports the results of omission of transfer RNA or the amino acid mixture from the complete cell-free system. Though both assay systems respond to transfer RNA or amino acid mixture, the effects are somewhat more pronounced in the amino acid-incorporation assay. Allen \& Schweet (1960) have presented evidence in support of the concept that amino acyl-transfer RNA is an obligatory intermediate in the incorporation of amino acids in the reticulocyte system. The influence of the amino acid mixture on the release of proteins therefore must be mediated through several sequences of reactions, i.e. reactions (1), (2) and (3). Thus the response of the protein-release

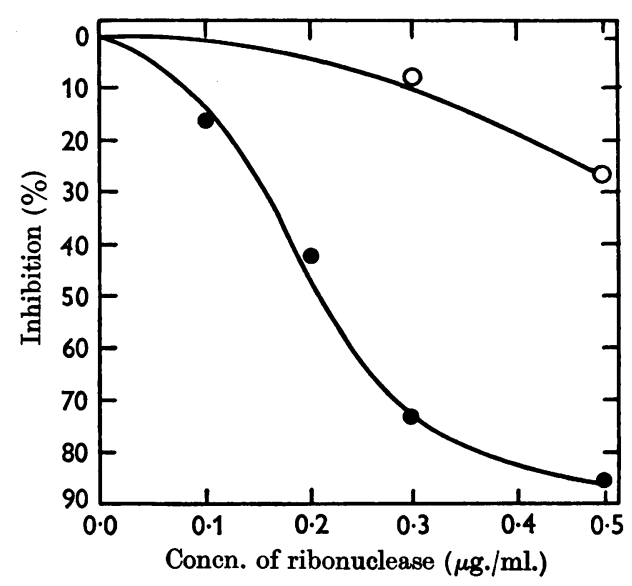

Fig. 2. Effects of ribonuclease on the incorporation of amino acids (O) and the release of proteins $(O)$ by ribosomes. Assay systems lacking the nucleoside triphosphates, ATP-generating system and [ $\left.{ }^{14} \mathrm{C}\right]$ leucine were preincubated with bovine ribonuclease for $5 \mathrm{~min}$. at $37^{\circ}$. The reaction mixtures were then chilled and the missing components were added (specific activity of [ $\left.{ }^{[4} \mathrm{C}\right]$ leucine $2.0 \mu \mathrm{o} / \mu \mathrm{mole}$ ). The reaction mixtures were then incubated as indicated for the complete assay system (see Table 2), except that transfer RNA was omitted from all assay systems. Incorporation, in the absence of ribonuclease, was 813 counts/min. Labelled whole-cell ribosomes contained 2115 counts/min. of ${ }^{14} \mathrm{C}$-labelled protein. The release of proteins in the absence of ribonuclease was $31 \%$ of the total ${ }^{14} \mathrm{C}$-labelled protein present. The values for the release of proteins have been corrected for ${ }^{14} \mathrm{C}$-labelled soluble protein present when nucleoside triphosphates and ATP. generating system were omitted, but ribonuclease was included as indicated. Counting was performed in the lowbackground counter (see the Methods section). 


\section{Table 1. Effects of amino acids and transfer ribonucleic acid on the incorporation of amino acids and the release of proteins by ribosomes}

The components of the complete system are those described in Table 2, except that 5 mg. of ${ }^{14} \mathrm{C}$-labelled whole-cell ribosomes (5213 counts/min.) was used for each protein-release assay system. Incorporation into $5 \mathrm{mg}$. of unlabelled ribosomes was determined with [ $\left.{ }^{1 /} \mathrm{C}\right]$ leucine (specific activity $2 \cdot 0 \mu \mathrm{c} / \mu \mathrm{mole}$ ). Incorporation in the complete system was 2352 counts/min. The release of ${ }^{14} \mathrm{C}$-labelled protein in the complete system was 2639 counts/min., as determined with the low-background counter (see the Methods section). Both the incorporation of amino acids and the release of proteins are expressed as percentages of the values obtained with the complete system.

\begin{tabular}{|c|c|c|}
\hline Assay components & $\begin{array}{c}\text { Incorporation of } \\
{\left[{ }^{14} \text { C]leucine }\right.} \\
(\%)\end{array}$ & $\begin{array}{c}\text { Release of } \\
{ }^{14} \mathrm{C} \text {-labelled protein } \\
(\%)\end{array}$ \\
\hline $\begin{array}{l}\text { Complete system } \\
\text { No transfer RNA added } \\
\text { No amino acid mixture added }\end{array}$ & $\begin{array}{r}100 \\
43 \\
45\end{array}$ & $\begin{array}{r}100 \\
65 \\
66\end{array}$ \\
\hline
\end{tabular}

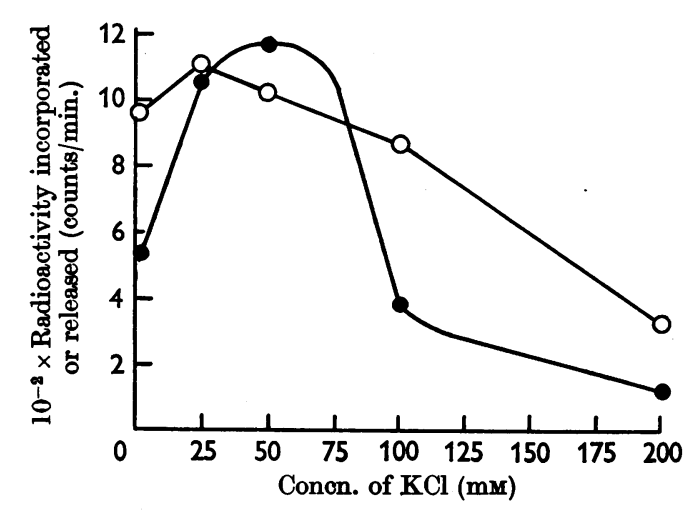

Fig. 3. Effect of $\mathrm{K}^{+}$ion concentration on the incorporation of amino acids (O) and the release of proteins (O) by ribosomes. Components of the complete system used are those indicated in Table 2, except that reagents free of $\mathrm{K}^{+}$ ions were utilized (see the Methods section). $\mathrm{KCl}$ was added as indicated. Labelled ribosomes contained 1785 counts/min. of ${ }^{14} \mathrm{C}$-labelled protein. The incorporation of amino acids was determined by using $\left[{ }^{14} \mathrm{C}\right]$ valine of specific activity $3 \cdot 0 \mu \mathrm{c} / \mu$ mole and multiplying by 2 .

assay to the presence, or absence, of the amino acid mixture gives a clear demonstration of a remote effect on a process in the protein-biosynthetic pathway.

The optimum concentration of $\mathrm{K}^{+}$ions was similar for both the incorporation of amino acids and the release of proteins, although the amino acid-incorporation process was more greatly depressed by extremes of $\mathrm{K}^{+}$ion concentration (Fig. 3). Studies of the effects of $\mathbf{M g}^{2+}$ ion concentrations have not been attempted owing to the critical role of that ion in the maintenance of ribosomal structure (Hamilton \& Petermann, 1959).

Further studies of the effects of the cell-free system components are presented in Table 2. Incubation of labelled ribosomes in the complete system (for $20 \mathrm{~min}$. at $37^{\circ}$ ) resulted in the release of approx. $60 \%$ of the bound radioactivity as soluble protein. Continued incubation did not lead to additional incorporation of amino acids or release of proteins. Neither incorporation of amino acids nor release of proteins occurred when the ATP. generating system and nucleoside triphosphates were omitted from the reaction mixtures. Omission of GSH led to a decrease of activity in both assay systems, suggesting that thiol-enzymes may be involved ubiquitously in both the incorporation of amino acids and the release of proteins.

Significant differences in the two assay systems were noted when soluble enzymes and nucleoside triphosphate requirements were examined. Omis sion of the purified supernatant enzyme fraction from the reaction mixtures decreased the incorporation of amino acids to $8 \%$ of the control value, but the release of proteins still proceeded at $28 \%$ of the maximal rate. In the presence of the supernatant enzyme fraction, $1 \mathrm{~mm}$-ATP supported the incorporation of amino acids and the release of proteins to about the same extent. On the other hand, $1 \mathrm{~mm}$-GTP enabled the release of proteins to proceed at $26 \%$ of the control rate when the incorporation of amino acids was only $5 \%$ of the maximal rate. Further differentiation of the incorporation of amino acids from the release of proteins was achieved in the presence of GTP by omitting the addition of supernatant enzymes. Thus the release of proteins proceeded at $30 \%$ of the maximal rate when incubated in the presence of only GTP, GSH, salts, buffer and those enzymic components that sedimented with the ribosomal particles. No significant incorporation of amino acids could be detected under these conditions.

The release of proteins in this isolated system did not depend on ATP, soluble enzymes, amino acid mixture or transfer RNA. By employing experimental conditions in which the incorporation of amino acids did not occur, it has thus been possible to study the release of protein from ribosomes as an isolated reaction, free from the influences of the polypeptide-forming processes. 
Table 2. Comparative requirements for the incorporation of amino acids and the release of proteins by ribosomes

The complete system contained tris- $\mathrm{HCl}$ buffer, $\mathrm{pH} 7.5$ (50 mM), $\mathrm{KCl}(50 \mathrm{~mm}), \mathrm{MgCl}_{2}(4 \mathrm{~mm})$, GSH, $\mathrm{pH} 6.5$ $(20 \mathrm{mM}), 19$ amino acids $(0.05 \mathrm{mM}$ each), unlabelled or labelled (specific activity $3.0 \mu \mathrm{o} / \mu$ mole) valine $(0.05 \mathrm{mM})$, saturating amounts of soluble enzyme $(6 \mathrm{mg}$.) and transfer RNA (150 $\mu \mathrm{g}$.), ribonucleoprotein $(3.0 \mathrm{mg}$.) from the cell-free preincubation procedures (see the Methods section) and nucleoside triphosphates as indicated, in a volume of $1.0 \mathrm{ml}$. The ATP-generating system consisted of phosphoenolpyruvic acid (5 mM) and pyruvate kinase $(20 \mu \mathrm{g} . / \mathrm{ml}$.$) . Both the incorporation of amino acids and the release of proteins are expressed as percentages$ of the values obtained with the complete cell-free system.

Concn. of nucleoside triphosphate

\begin{tabular}{|c|c|c|c|c|c|}
\hline $\begin{array}{l}\operatorname{ATP} \\
(\mathbf{m M})\end{array}$ & $\begin{array}{l}\text { GTP } \\
(\mathbf{m M})\end{array}$ & $\begin{array}{l}\text { Generating } \\
\text { system }\end{array}$ & Omissions from complete system & $\begin{array}{c}\text { Incorporation of } \\
{\left[{ }^{4} \mathrm{C}\right] \text { valine }} \\
(\%)\end{array}$ & $\begin{array}{c}\text { Release of } \\
{ }^{14} \mathrm{C} \text {-labelled protein } \\
(\%)\end{array}$ \\
\hline $\begin{array}{l}1.0 \\
0 \\
1.0 \\
1.0 \\
1.0 \\
0 \\
1.0 \\
0\end{array}$ & $\begin{array}{l}0.25 \\
0 \\
0 \cdot 25 \\
0 \cdot 25 \\
0 \\
1 \cdot 0 \\
0 \\
1 \cdot 0\end{array}$ & $\begin{array}{l}+ \\
- \\
+ \\
+ \\
- \\
- \\
- \\
-\end{array}$ & $\begin{array}{l}\text { None } \\
\text { None } \\
\text { Soluble enzymes } \\
\text { GSH } \\
\text { None } \\
\text { None } \\
\text { Soluble enzymes } \\
\text { Soluble enzymes, transfer RNA } \\
\text { and amino acid mixture }\end{array}$ & $\begin{array}{c}100 \\
0 \\
8 \\
8 \\
51 \\
5 \\
0.7 \\
0.2\end{array}$ & $\begin{array}{r}100 \\
0 \\
28 \\
10 \\
50 \\
26 \\
13 \\
30\end{array}$ \\
\hline
\end{tabular}

\section{Characteristics of the isolated protein-release reaction}

Total ${ }^{14} \mathrm{C}$-labelled-protein content in the proteinrelease assay system. Though the labelled ribosomes employed for the protein-release studies had been isolated by sedimentation from very dilute solutions (see the Methods section) the possibility remained that some amino acyl-transfer RNA had sedimented with the ribosomal particles. Reincubation of such ribosomes might permit incorporation to proceed from the bound amino acids, if not from free amino acids. However, the results in Table 3 indicate that no increase in total radioactive protein occurred during incubation under the conditions employed for the study of the isolated protein-release reaction. Hence incorporation from amino acyl-transfer RNA was not a significant factor in the present work. This conclusion is supported by the relative insensitivity of the release of proteins to low concentrations of ribonuclease (Fig. 2). Rapid loss of biological activity of transfer RNA on incubation with concentrations of bovine ribonuclease similar to those reported in the present paper has been shown by Nishimura \& Novelli (1963).

Nucleoside triphosphate specificity of the release of proteins. As mentioned above, 1 mM-GTP was more effective for the release of proteins than was 1 mM-ATP. Table 4 presents the results of a comparative study of the effects of four nucleoside triphosphates on the incorporation of amino acids and the release of proteins under the experimental conditions of the isolated protein-release reaction. The specific effect of GTP in the protein-release reaction was clearly evident; other nucleoside triphosphates possessed minimal activity. No signifi-
Table 3. Effect of incubation on the ${ }^{14} \mathrm{C}$-labelledprotein content of the protein-release assay system

After $40 \mathrm{~min}$. incubation at $37^{\circ}$, protein was precipitated with $5 \%$ trichloroacetic acid and analysed for ${ }^{14} \mathrm{C}$-labelled protein (see the Methods section). The isolated proteinrelease assay system contained GSH $(20 \mathrm{~mm})$, tris- $\mathrm{HCl}$ buffer, $\mathrm{pH} 7.5(50 \mathrm{mM}), \mathrm{KCl}(50 \mathrm{mM}), \mathrm{MgCl}_{2}(4 \mathrm{mM})$, ribonucleoprotein $(3.0 \mathrm{mg}$.) from the cell-free preincubation procedures (see the Methods section) and GTP as indicated, in a final volume of $1.0 \mathrm{ml}$.

$\begin{array}{lc}\text { Experimental } & \begin{array}{c}\text { Total } \\ \text { conditions }\end{array} \\ \begin{array}{c}\text { probelled } \\ \text { protein } \\ \text { (counts/min.) }\end{array} \\ \text { No incubation } & 945 \\ \text { No GTP added } & 930 \\ \text { 0.1 mM-GTP present } & 920\end{array}$

Table 4. Nucleoside triphosphate specificity for the release of proteins from ribosomes

Components of the cell-free systems are those of the isolated protein-release assay system shown in Table 3. Nucleoside triphosphate concentrations were $0.1 \mathrm{~mm}$. Labelled ribosomes contained 1785 counts/min. of ${ }^{14} \mathrm{C}$ labelled protein. Incorporation of $\left.{ }^{14} \mathrm{C}\right]$ valine (specific activity $3.0 \mu \mathrm{c} / \mu \mathrm{mole}$ ) in the complete cell-free system (Table 2) was 1605 counts/min. Incubations were for $20 \mathrm{~min}$. at $37^{\circ}$.

\begin{tabular}{|c|c|c|}
\hline $\begin{array}{l}\text { Nucleoside } \\
\text { triphosphate } \\
\text { added }\end{array}$ & $\begin{array}{c}\text { Incorporation of } \\
{\left[{ }^{14} \mathrm{C}\right] \mathrm{s} \text { aline }} \\
\text { (counts/min.) }\end{array}$ & $\begin{array}{c}\text { Release of } \\
{ }^{14} \text { C-labelled } \\
\text { protein } \\
\text { (counts/min.) }\end{array}$ \\
\hline $\begin{array}{l}\text { GTP } \\
\text { ATP } \\
\text { CTP } \\
\text { UTP } \\
\text { None }\end{array}$ & $\begin{array}{l}\mathbf{5} \\
\mathbf{2} \\
\mathbf{3} \\
\mathbf{1} \\
\mathbf{0}\end{array}$ & $\begin{array}{r}237 \\
26 \\
49 \\
49 \\
0\end{array}$ \\
\hline
\end{tabular}


cant incorporation of amino acids occurred with any one of those substances tested.

Some general properties of the isolated proteinrelease reaction. Results of studies undertaken to determine the stability of the ribosomal preparations and other general properties of the proteinrelease reaction are reported in Tables 5 and 6 . The dependence of the release of proteins on the presence of GSH was apparent in the isolated proteinrelease reaction and tended to substantiate the similar observation reported in Table 2. Activity in the protein-release assay was found to be diminished significantly by storage of the ribosomal suspensions at $4^{\circ}$ for $24 \mathrm{hr}$. or by repeated freezing and thawing. Prolonged storage of the ribosomes at $-18^{\circ}$ is accompanied by a decline in activity. Though the loss of activity varied considerably with different ribosomal preparations, $-18^{\circ}$ for 1 month usually resulted in the loss of about onehalf of the protein-release activity.

The addition of spermine to the reticulocyte system was reported by Morris \& Schweet (1961) to inhibit completely the appearance of ${ }^{14} \mathrm{C}$-labelled

Table 5. Effects of reduced glutathione and spermine on the release of proteins from ribosomes

Ribosomes, from the cell-free preincubation procedure, contained 2043 counts $/ \mathrm{min}$. of ${ }^{14} \mathrm{C}$-labelled protein. The GTP concentration used was $0.25 \mathrm{~mm}$. Incubations were for $20 \mathrm{~min}$. at $37^{\circ}$.
Changes in the isolated protein-release assay system

None

Spermine (1 mM) added
No GSH added
Release of ${ }^{14} \mathrm{C}$-labelled protein

$\begin{array}{cc}\text { (counts/ } & \begin{array}{c}(\% \text { of } \\ \text { min.) } \\ \text { maximum })\end{array} \\ 322 & 100 \\ 82 & 25 \\ -83 & -\end{array}$

Table 6. Effects of storing ribosomes on the release of proteins

Ribosomes, from the cell-free preincubation procedure, containing 4060 counts/min. of ${ }^{14} \mathrm{C}$-labelled protein, were treated as indicated and incubated in the isolated proteinrelease assay system (see Table 3). The assay systems were then centrifuged in the presence of $10 \mathrm{~mm}-\mathrm{MgCl}_{2}$. Radioactivity was determined in the low-background counter (see the Methods section). Incubations were for $20 \mathrm{~min}$. at $37^{\circ}$.

$\begin{array}{llcc}\begin{array}{c}\text { Pretreatment of } \\ \text { labelled ribosomes }\end{array} & \begin{array}{c}\text { GTP } \\ (\mathrm{mM})\end{array} & \begin{array}{c}\text { (counts/ } \\ \text { min.) }\end{array} & \begin{array}{c}\text { (\% of } \\ \text { maximum) }\end{array} \\ \text { None } & 0 \cdot 25 & 888 & 100 \\ & 0 & 273 & - \\ 4^{\circ} \text { for } 24 \mathrm{hr} . & 0 \cdot 25 & 755 & 74 \\ & 0 & 296 & - \\ \text { Frozen and thawed } & 0 \cdot 25 & 746 & 72 \\ \text { six times } & 0 & 299 & -\end{array}$

soluble protein, as well as to inhibit the incorporation of amino acids in the reticulocyte system. The isolated protein-release assay system showed a similar effect with the addition of spermine, resulting in even less ${ }^{14} \mathrm{C}$-labelled soluble protein than was found when GTP was omitted from the assay. Aggregation of ribosomal particles by spermine has been reported by Siekevitz \& Palade (1962). The low value reported in the present paper is probably due to more complete removal of ribosomal particles during centrifugation. The presence of 10 mM-magnesium chloride during centrifugation, which also produces ribosomal aggregation (Hamilton \& Petermann, 1959), has proved useful by decreasing ${ }^{14} \mathrm{C}$-labelled-protein values as a result of incomplete sedimentation of ribosomes.

The appearance of ${ }^{14} \mathrm{C}$-labelled protein in the supernatant proceeded almost linearly for $40 \mathrm{~min}$. in the presence of GTP (Fig. 4). After that time a slow continued increase was observed that was similar in rate to that found when GTP had been omitted. Prolonged incubation is thought to result in a limited amount of ribosomal breakdown. For those incubation periods employed in the present studies (20 and $40 \mathrm{~min}$.) ribosomal breakdown was not a significant factor.

The amount of ${ }^{14} \mathrm{C}$-labelled protein released by the addition of GTP was $26 \%$ of the total ${ }^{14} \mathrm{C}$ labelled protein present in the assay. Ribosomes

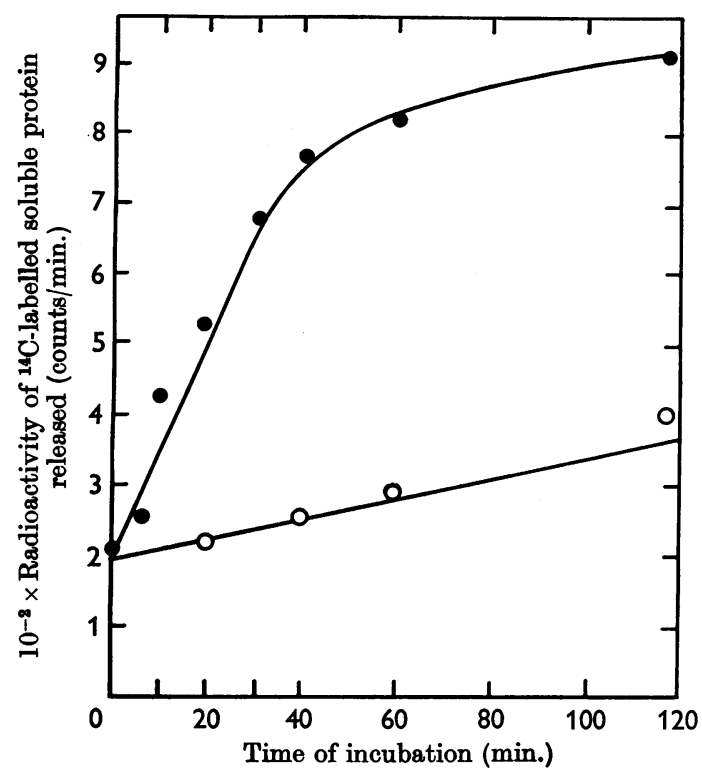

Fig. 4. Appearance of ${ }^{14} \mathrm{C}$-labelled soluble protein from prelabelled ribosomes in the presence $(O)$ and absence $(O)$ of $1 \mathrm{~mm}-\mathrm{GTP}$. The components of the isolated proteinrelease system are as indicated in Table 3. Ribosomes contained 1990 counts/min. of ${ }^{14} \mathrm{C}$-labelled protein. 


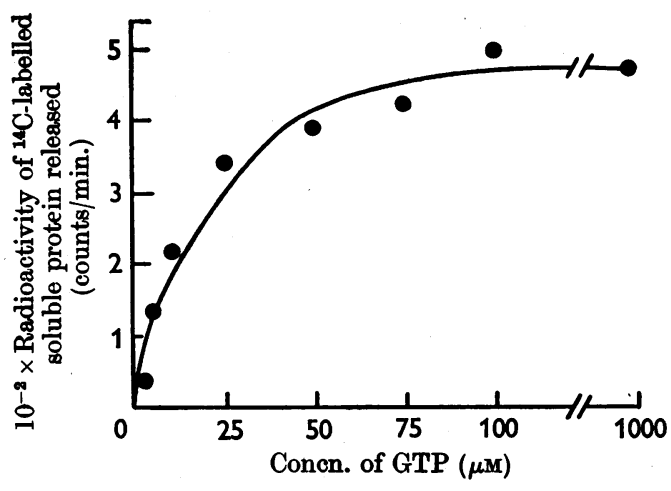

Fig. 5. Dependence of the isolated protein-release reaction on the GTP concentration. Assay components (seo Table 3) were incubated for $40 \mathrm{~min}$. at $37^{\circ}$. Ribosomes contained 1935 counts/min. of ${ }^{14} \mathrm{C}$-labelled protein.

that had been labelled in the intact reticulocyte gave a similar release.

Quantitative aspects of the guanosine triphosphate requirement in the release of proteins. Incubation for $40 \mathrm{~min}$. at $37^{\circ}$ with as little as 1-5 $\mu \mathrm{M}$-GTP resulted in a measurable release of proteins, and release was one-half maximal with $12 \mu \mathrm{M}$-GTP (Fig. 5). The reaction became saturated in the presence of 0.1 mM-GTP. In contrast, the ATP concentration that gives maximal incorporation of amino acids in the complete cell-free system has been reported to be 1-2 mM in the presence of an ATP-generating system, and even greater concentrations are required if the ATP-generating system is omitted (Allen \& Schweet, 1962).

Nature of the soluble protein. Labelled protein from the supernatant fraction of the cell-free protein-release assay system was combined with carrier haemoglobin and chromatographed as such or after conversion into globin (see the Methods section). No radioactivity was found in the haemoglobin peak eluted from a column of Amberlite CG-50. Of 7540 counts/min. of ${ }^{14} \mathrm{C}$-labelled protein placed on the column, only 329 counts/min. were eluted (recovery 5\%). A preparation of globin added to this column was retained similarly under these conditions. The product of the isolated protein-release reaction does not appear to be the finished haemoglobin molecule.

By chromatography on a CM-cellulose column radioactive protein was found to be distributed throughout the $\alpha$-and $\beta$-chain peaks, indicating the presence of globin chains that were complete with respect to polypeptide structure (Figs. $6 a$ and $6 b$ ). The displacement of the $\alpha$-chain radioactivity towards the front of the carrier $\alpha$-chain peak, seen in Fig. $6(b)$, has been noted by other workers. Though the displacement is not well understood, it is known to be associated with the chromato-
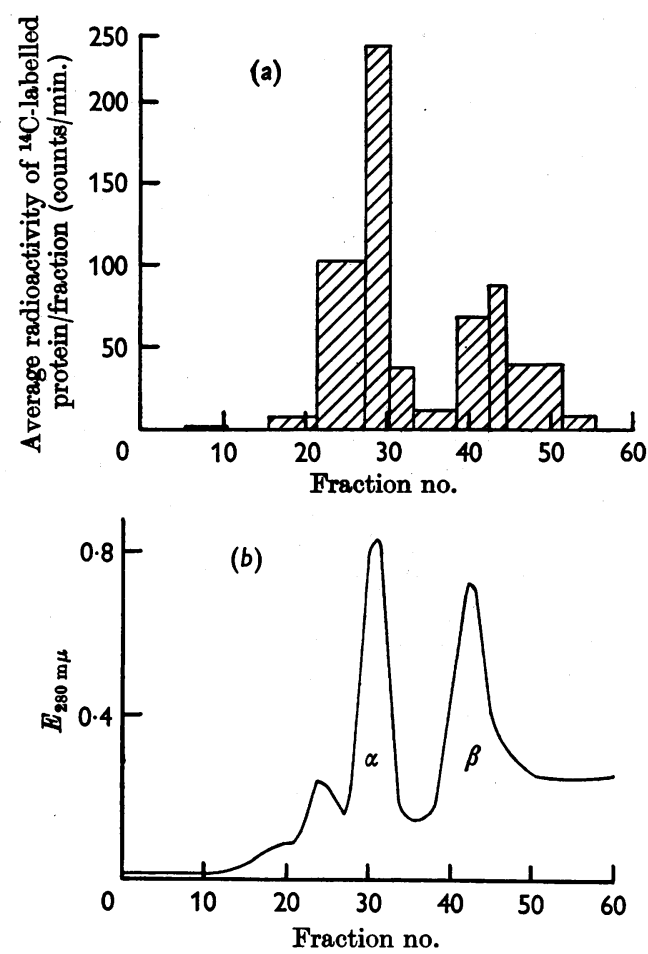

Fig. 6. Chromatographic comparison of the ${ }^{14} \mathrm{C}$-labelled soluble protein produced by the isolated protein-release reaction with the globin chains of rabbit haemoglobin (see the Mothods section for details). (a) Elution pattern of ${ }^{14} \mathrm{C}$-labelled protein. The recovery of added ${ }^{14} \mathrm{C}$-labelled protein was $72 \%$ of the recovery of the globin carrier protein. (b) Elution pattern of the $\alpha$ - and $\beta$-globin chains of rabbit haomoglobin from CM-cellulose.

graphy of cell-free synthesized $\alpha$-chains of globin in the chromatographic system employed (Ehrenstein, Weisblum \& Benzer, 1963).

\section{DISCUSSION}

The ability of the protein-release reaction to proceed under conditions that did not support peptide-bond formation has demonstrated that the two processes are not rigidly linked to one another. This finding suggests that after completion of the polypeptide sequence finished globin chains remain bound to the ribosomal particles until removal by the protein-release reaction.

The effect of the amino acid-incorporating system in stimulating the release of ${ }^{14} \mathrm{C}$-labelled protein probably involves completion of polypeptide structure by the addition of a full complement of amino acids to the ${ }^{14} \mathrm{C}$-labelled partial peptide chains on the ribosome (Morris, Arlinghaus, Favelukes \& Schweet, 1963). These protein mole- 
cules then could act as substrates for the proteinrelease reaction. Thus, when incubated in the complete cell-free system, approx. $60 \%$ of the ribosomal-bound ${ }^{14} \mathrm{C}$-labelled protein appeared in the supernatant phase by a combination of completion of protein chains and release of protein molecules from the ribosomes. With those experimental conditions used for the study of the isolated protein-release reaction, where the completion process was inoperative, $26 \%$ of the ribosomalbound radioactivity was transferred to the supernatant fraction.

Reticulocyte ribosomes, incubated in the presence of the valine analogue $\alpha$-amino- $\beta$-chlorobutyric acid, have been reported to be blocked in the release of newly synthesized polypeptides (Rabinovitz \& Fischer, 1962). Such ribosomal preparations, however, did participate in the incorporation of radioactive iron into soluble haemoglobin. The existence of 'preformed protein precursors' bound to the ribosomal particles was proposed to explain these observations (Rabinovitz \& McGrath, 1959).

Several reports have appeared describing the existence of firmly bound enzymic activity on ribosomes from micro-organisms. Kinetic and other studies in these systems have indicated that the bound protein was the precursor of the soluble enzyme (Kihara, Hu \& Halvorson, 1961; Cowie, Spiegelman, Roberts \& Duerksen, 1961 ; Duerksen \& O'Connor, 1963).

Studies with the isolated protein-release system have not, as yet, permitted the construction of an assay system that would allow the isolation of the enzymic component of the protein-release reaction. Such an assay system would require an initial removal of the enzyme from the ribosome while retaining the bound preformed proteins on the ribosome. The assay system must also distinguish between the effects of an increased amount of substrate due to the completion of protein chains and the protein-release reaction itself. However, the properties of the protein-release reaction do resemble sufficiently the characteristics of an enzyme-catalysed process to suggest strongly the intervention of an enzyme. In particular, the appearance of soluble protein is strongly dependent on the presence of a thiol (GSH) and specifically requires GTP. The conditions and time of storage of the ribosomal preparations influence the observed protein-releasing activity of the system. One may speculate that the close association of the enzymic factor with the ribosomal particles is of functional significance.

Though the interrelationships of the incorporation of amino acids and the release of proteins caused considerable difficulty in the interpretation of results during the initial stages of the present work, the influence that the factors required for the incorporation of amino acids exert on the release of proteins gives a clear demonstration of the integrated nature of the biosynthetic pathway of protein formation. Specifically, it has led this author to regard with reservation the assignment of a specific function to a reactant in a cell-free system where it has not been possible to isolate the reaction under investigation (usually by radioactivity transfers) from the effects of other (unlabelled) processes that may actually be determining the fate of the experiment.

GTP may be another example of a substance that influences the rate of reactions in which it is not directly involved. The locus of action of GTP was originally assigned to the transfer of amino acids from transfer RNA to ribosomes (see Simkin, 1959), and more recently has been reassigned to the process of polymerization of amino acids into peptide linkage (Noll, Staehelin \& Wettstein, 1963). The present study indicates that one point of action of GTP is the release of protein from ribosomes, as demonstrated in a cell-free system where neither the transfer nor the polymerization reactions occurred. Though it is conceivable that GTP may have more than one point of action, remote effects on the amino acid-incorporation process could produce an apparent requirement for GTP at several sites in the biosynthetic pathway.

Although the exact function of GTP in the release of proteins remains a point for further investigation, it is suggested that GTP participates directly, either as a cofactor or an energy source, in the reaction that frees the finished protein chain from its attachment to the ribosome.

\section{SUMMARY}

1. The release of ${ }^{14} \mathrm{C}$-labelled protein from previously ${ }^{14} \mathrm{C}$-labelled reticulocyte ribosomes, and the incorporation of ${ }^{14} \mathrm{C}$-labelled amino acids into unlabelled ribosomes prepared in a parallel manner, have been determined in order to assess the influence of the incorporation of amino acids on the release of proteins in a cell-free system.

2. The protein-release process has been found to consist of two distinct steps, each possessing different requirements. The first step consists of those processes involved in the completion of protein chains before release from the ribosome. The second step, the release of protein from the ribosome, has been shown to proceed independently of the completion process.

3. An absolute requirement for the presence of GTP has been demonstrated in the protein-release reaction.

4. Characterization of the soluble product of the protein-release reaction has shown the presence of 
the $\alpha$ - and $\beta$-globin chains of haemoglobin which are not yet in the form of the finished haemoglobin molecule.

The author is grateful to Dr Thomas S. Work, whose generous support, assistance and encouragement has enabled the present study to be accomplished. The expert technical help of Miss Ann Stevens is appreciated. This work was performed during the tenure of a postdoctoral fellowship from the National Heart Institute, U.S. Public Health Service.

\section{REFERENCES}

Allen, D. W., Schroeder, W. A. \& Balog, J. (1958). J. Amer. chem. Soc. 80, 1628.

Allen, E. \& Schweet, R. (1960). Biochim. biophys. Acta, 39, 185.

Allen, E. \& Schweet, R. (1962). J. biol. Chem. 237, 760.

Arnstein, H. R. V. (1961). Biochem. J. 81, 24P.

Borsook, H., Deasy, C. L., Haagen-Smit, A. J., Keighley, G. \& Lowy, P. H. (1952). J. biol. Chem. 196, 669.

Borsook, H., Fischer, E. H. \& Keighley, G. (1957). J. biol. Chem. 229, 1059.

Chao, F. (1957). Arch. Biochem. Biophys. 70, 426.

Cowie, D. B., Spiegelman, S., Roberts, R. B. \& Duerksen, J. D. (1961). Proc. nat. Acad. Sci., Wash., 47, 114.

Dintzis, H. M. (1961). Proc. nat. Acad. Sci., Wash., 47, 247.

Dintzis, H. M., Borsook, H. \& Vinograd, J. (1958). In Microsomal Particles and Protein Synthesis, p. 95. Ed. by Roberts, R. B. New York: Academic Press Inc.

Duerksen, J. D. \& O'Connor, M. L. (1963). Biochem. biophys. Res. Commun. 10, 34.

Ehrenstein, G. von, Weisblum, B. \& Benzer, S. (1963). Proc. nat. Acad. Sci., Wash., 49, 669.

Hamilton, M. G. \& Petermann, M. L. (1959). J. biol. Chem. 234, 1441.

Hultin, T., Leon, H. A. \& Cerasi, E. (1961). Exp. Cell Res. 25,660 .

Kihara, H. K., Hu, A. S. L. \& Halvorson, H. O. (1961). Proc. nat. Acad. Sci., Wash., 47, 489.

Kruh, J. \& Borsook, H. (1956). J. biol. Chem. 220, 905.
Lingrel, J. B. \& Borsook, H. (1963). Biochemistry, 2, 309.

Lowry, O. H., Rosebrough, N. J., Farr, A. L. \& Randall, R. J. (1951). J. biol. Chem. 193, 265.

Margoliash, E. (1961). Annu. Rev. Biochem. 80, 549.

Matthaei, J. H. \& Nirenberg, M. W. (1961). Proc. nat. Acad. Sci., Wash., 47, 1580.

Morris, A. J. (1963). Biochem. biophys. Res. Commun. 11, 201.

Morris, A. J., Arlinghaus, R., Favelukes, S. \& Schweet, R. S. (1963). Biochemistry, 2, 1084.

Morris, A. J. \& Schweet, R. S. (1961). Biochim. biophys. Acta, 47, 415.

Neuberger, A. \& Niven, J. S. F. (1951). J. Physiol. 112 , 292.

Nishimura, S. \& Novelli, G. D. (1963). Biochem. biophys. Res. Commun. 11, 161.

Noll, H., Staehelin, T. \& Wettstein, F. O. (1963). Nature, Lond., 198, 632.

Oyama, V. I. \& Eagle, H. (1956). Proc. Soc. exp. Biol., N.Y., 91, 305.

Rabinovitz, M. \& Fischer, J. M. (1962). Biochim. biophys. Acta, 61, 644.

Rabinovitz, M. \& McGrath, H. (1959). J. biol. Chem. 234, 2091.

Rabinovitz, M. \& Olson, M. E. (1958). Nature, Lond., 181, 1665.

Rabinovitz, M. \& Olson, M. E. (1959). J. biol. Chem. 234, 2085.

Sachs, H. (1957). J. biol. Chem. 228, 23.

Schweet, R., Lamfrom, H. \& Allen, E. (1958). Proc. nat. Acad. Sci., Wash., 44, 1029.

Siekevitz, P. \& Palade, G. E. (1962). J. Cell Biol. 13, 217.

Simkin, J. L. (1958). Biochem. J. 70, 305.

Simkin, J. L. (1959). Annu. Rev. Biochem. 28, 145.

Simpson, M. V. (1962). Annu. Rev. Biochem. 31, 333.

Tissieres, A.\& Watson, J. D. (1958). Nature, Lond., 182, 778.

Wallace, J. M., Squires, R. F. \& Ts'o, P. O.P. (1961). Biochim. biophys. Acta, 49, 130.

Warburg, O. \& Christian, W. (1942). Biochem. Z. 310, 384.

Warner, J. R., Rich, A. \& Hall, C. E. (1962). Science, 138 , 1399.

\title{
The Metabolism of Glucose 1-Phosphate and Glucose 6-Phosphate and their Influence on the Metabolism of Glucose in Rat-Diaphragm Muscle
}

\author{
By ANNE BELOFF-CHAIN, P. BETTO, RAFFAELLA CATANZARO, E. B. CHAIN, \\ L. LONGINOTTI, INES MASI AND F. POCCHIARI \\ International Centre for General Biochemistry and Chemical Microbiology, Istituto Superiore di Sanita, \\ Rome, Italy
}

(Received 23 December 1963)

In a previous investigation carried out in this Laboratory (Beloff-Chain et al. 1953) it was found that isolated rat diaphragm synthesized glycogen from glucose and from glucose 1-phosphate to about the same extent when the substrate concentration, calculated as glucose, was $2 \%$. There was little or no glycogen synthesis from glucose 6-phosphate at this concentration. Further, it was shown that insulin had no stimulatory effect on glycogen synthesis from glucose 1-phosphate as it had from glucose. 